\title{
HISTORICAL RESEARCH THROUGH COIN HOARDS
}

\begin{abstract}
This discussion highlights the significance of often overlooked coin hoards in historical studies of the Roman Empire. It analyses the problems of incorporating numismatics as a means for studying ancient Roman history. The main part of the discussion focuses on the reliability level of hoard analysis and the possible pitfalls that lead to an insufficiently critical interpretation. In the example of two fourth-century Roman hoards from Slovenia, the Emona and the Čentur hoards, the author tries to show what such studies can bring, and with which challenges historians are faced with while studying coin hoards. She also explores how new approaches to studying coin hoards could help to integrate their studies into the study of classical history.
\end{abstract}

Keywords: Numismatics, coin hoards, history, historical sources, Emona, Čentur.

\section{HISTORY THROUGH NUMISMATICS}

$\mathbf{N}$

owadays, we have far surpassed our understanding of the past as a merely political or military history of great events and personalities. To fully comprehend history's complexities, we must take into consideration its often overlooked facets such as economic, social and cultural history or history of art - which should complement each other. An under-utilized field for studying history is numismatics. In the field of classical studies, where the quantity of ancient sources is very limited, the coins used in people's everyday lives represent an important source of information. Despite the fact that coins cannot compare with written sources in the expressiveness of complex political events, they do have other advantages. Coins, preserved in large quantities, always reflect the public sphere, as the state itself was responsible for their definition and value. Overall, coins testify directly about the time in which they were created and therefore do not have the

\footnotetext{
${ }^{1}$ The author is grateful to Mary N. Lannin (New York) for her assistance in correcting her written English.
}

\section{Leilani Štajer ${ }^{1}$}

University of Primorska

leilanistajer@gmail.com

DOI: $10.14795 /$ j.v7i1_SI.494

ISSN 2360 - 266X

ISSN-L 2360 - 266X 
disadvantage of retrospective records. ${ }^{2}$ Since many ancient Roman coins refer to historical events such as wars, conquests, constructions or reconstructions of public monuments, or public festivities, coins provide us an important insight about state religions, cult, political thought, ideology, art and monetary system. $^{3}$

Despite all this, and the famous quote by Jean Babelon about numismatics being an historical auxiliary science, ${ }^{4}$ scholars concerned with the ancient world such as ancient historians and excavators tend not to take enough notice of numismatics. ${ }^{5}$ Perhaps one of the reasons is the difficulty in connecting coin studies directly to their research. However, the main reason might lie in numismatists' failure to give a straight answer to straight questions. So many aspects of coin studies are devoted to methods rather than conclusions. ${ }^{6}$ And those scholars who do study coins face many recurring problems, especially when approaching the study of coin hoards, which is quite different from studying coin types or individual coin finds. With careful interpretation, hoards can be one of the most important sources for studying the ancient economic, political and military history of a particular territory, especially if based on the analysis of several contemporaneous hoards.

\section{CHALLENGES IN THE STUDY OF COIN HOARDS - DISCOVERY AND DATING}

There are many recurring challenges a historian faces when studying coin hoards, the first being the circumstances of the discovery. Whenever a coin hoard derives from archaeological excavations it is possible to determine precisely the chronological order

\footnotetext{
2 HOWGEGO 1997, 62.

3 FITZWILLIAM MUSEUM.

${ }^{4}$ "Science auxiliaire de l'histoire, dit-on, la numismatique se résigne difficilement à ce rôle ancillaire« BABELON 1961, 329.

5 REECE s.d.

6 Some scholars might find it difficult to take in diagrams and large numbers as these are uncommon elements for research in the humanities. REECE s.d.
}

of individual archaeological stratigraphic units and to date the rest of the chronologically less-tangible artefacts, discovered within the same layers of soil. Three dates should be applied to coin hoards: the date at which the majority of coins were assembled, the date of the latest coin in the hoard and the estimated date at which the hoard was buried. ${ }^{7}$ The most recent coin is of critical importance and the identification of the mint and estimated striking date helps to determine the terminus post quem of the hoard. ${ }^{8}$ The date at which the latest coin was struck is reasonably easy to determine and reasonably secure, but it is almost impossible to determine when that coin was added to the hoard. To use that date as the time of the burying of the hoard may be correct, but we have no way of confirming that. The only firm way to date it is by a stratigraphic argument on the position of the hoard in a dated excavated sequence. ${ }^{9}$ Therefore coins published from a site without archaeological context (the deposit in which they were found described in its stratigraphic position) cannot give us safe, reliable information.

Fully documented coin hoards can enable precise determination of the time of the archaeological layer in which it was found, as well as clarify a number of other questions connected with the flow of money in circulation, with the relative chronology of individual coins or coin emissions, and monetary history in general. This is only possible if the data concerning the site is determined and documented as accurately as possible. Therefore, when dealing with coin hoards the quantity (the number of pieces found) is certainly not as important as quality (carefully documenting the context of all coin finds). ${ }^{10}$ In the interpretation of coin finds, if considering coins to be an absolute chronological factor, we must take into account the 'delay factor', which is the time the coin entered circulation after minting in

\footnotetext{
7 REECE s.d.

8 KOS 1997, 107.

9 REECE s.d.

10 KOS 1997, 114.
} 
the region* of its later hoarding, which is fairly unreliable. In the interpretation, we must pay attention to how much the coin had been used at the time of its burial, by examining its condition (its wear), since the greater or lesser use of a coin is an important element in establishing objectively how long the coin was in circulation before becoming part of the site. ${ }^{11}$ An analysis of coin hoards should always respect the composition of the hoard. The size of the hoard can reveal whether the hoard was personal property, family wealth or official character, although only the circumstances of the discovery can reveal whether they were military or civilian treasures. ${ }^{12}$ The appearance of coins from individual coin periods and in the context as well as the appearance of coins of individual mints should be taken in consideration as well. An analysis of the appearance of coins of individual mints very often show that in terms of monetary mass, coins from the nearest mint to the site always predominate, which also reflects the currency circulation. ${ }^{13}$

Since most hoards are discovered by accident, the first person to come in contact with them is rarely trained to handle archaeological artefacts properly. In many cases, archaeological sites are damaged due to unearthing with the careless use of metal detectors and shovels. ${ }^{14}$ And whenever on-site data is superficially determined or documented, both the expressive value and

\footnotetext{
11 KOS 1997a, 115.

12 MIŠKEC 2002, 380.

13 The analysis of the representation of mints helps us establish, mainly in the fourth century, the affiliation of some regions of the Roman empire to the spheres of interest of individual rulers. For example, in 318-324 the worsening of relations between the legitimate Emperors Constantine the Great and Licinius had an impact on monetary circulation. The coins from Western mints could not easily penetrate East and vice versa. See G. L. Duncan, Coin Circulation in the Danubian and Balkan Provinces of the Roman Empire AD 294-578 (London 1993) 9. KOS 1997a, 115.

14 On the catastrophic plundering of archaeological remains in Bavaria, see KELLER 1992, 6. For Syria, see WARTENBERG KAGAN 2015. Such examples apply for most source countries, including Slovenia.
}

the possibility of accurate dating, which otherwise make coins one of the most important historical primary sources, will significantly diminish. Here too, there have been some inconsistencies in the past that were linked to a catalogue presentation and later interpretation of coin hoards. In the event that we only have information about a small proportion of a bigger find, there is a high probability that precisely the most recently struck coins in the find will be missing, since they are likely to also have been the best preserved and thus of most interest on the numismatic market. ${ }^{15}$ This is the most common problem with hoards which haven't been discovered in the context of archaeological excavations. Establishing the time and cause of burial of such rudimentarily preserved or documented hoards cannot be objectively established.

\section{THE PROBLEMS OF HOARD ANALYSIS AND INTERPRETATION}

The circumstances regarding the context of a hoard are of paramount importance. However, quite a lot of information can be derived from the distribution of coins from area to area without any stratigraphic information, and coins found together in a single deposit do have a context which is often greatly improved by similar deposits. A good example of area studies is the late first / early second centuries silver coins which show Zeus Ammon on the reverse: they had been attributed to Caesaraea in Cappadocia, but are found in North Africa., and their find spots - judged in geographical rather than stratigraphic terms - made it reasonably clear that they belong not to Asia Minor but to Cyrene. ${ }^{16}$

Coins from archaeological contexts can also tell us who the intended audience was. ${ }^{17}$ The study of the hoards' geographic distribution displays an evident pattern: the higher the number of stationed soldiers, the

\footnotetext{
15 KOS 1997a, 114.

16 AMANDRY, BURNETT 2015 in: REECE s.d.

17 ELKINS 2009, 43.
} 
higher the numbers of hoards that are found. ${ }^{18}$ In her doctoral dissertation on the coin finds from the legionary fortress at Nijmegen, Fleur Kemmers came to the conclusion that certain coin types were selected to supply the soldiers stationed at Nijmegen during the Flavian period. ${ }^{19}$ Kemmers compared finds from a particular site to local and regional finds and discovered that that a certain population was supplied - deliberately - with certain coin types relevant to its station in Roman society. ${ }^{20}$

Inmanycases archaeologists and classical historians wish to link the interpretation of coin hoards to historical events reported in historical sources. However, if the hoard has not been preserved or documented in entirety, or the most recent coin in the hoard only approximately corresponds with the events mentioned in written sources, one might even speak of an abuse of historical source material, as the necessary objectivity in its evaluation is entirely lacking. ${ }^{21}$ The methodological issue, that incomplete hoards are often interpreted without paying attention to the fact that they are incomplete, though they should instead be studied with a critical eye, has already been raised by Pierre Assenmaker in his paper on the dating of Roman coinage between the years $88-82 .{ }^{22}$

Another recurring mistake in the interpretation of coin hoards is that any

\footnotetext{
18 DUNCAN-JONES 1994, 72-75.

19 KEMMERS 2007.

20 PETER 1996 may be viewed as a precursor to Kemmers' work in some respects in that it sought to examine the differences in coin types circulating in different regions. ELKINS 2009, 43.

${ }^{21}$ The classical case of such a methodologically mistaken interpretation of a coin hoard is the account in NOLL 1954 of a series of hoards whose original structure had not been documented in entirety or was unknown. It is possible to find similar cases in the area of the Roman province of Raetia, which historical sources claim to have been abandoned at the time of Emperor Gallienus. KELLNER 1972, 150, chose seventeen coin hoards which were supposed to have concluded with coins of Gallienus, but made serious methodological mistakes in the interpretation of the coin hoards, and actually unwittingly abused the material historical source. In: KOS 1997a, 114.
}

${ }^{22}$ ASSENMAKER 2016, 100-102. burial of a large group of coins was caused by some hostile action. Michael Crawford notably considers that there is an increase of hoards in periods of violence, although the small territory and short chronological period which he studied did not allow him to reach a definitive conclusion on this aspect. ${ }^{23}$ Instead, Richard Duncan-Jones considers that time of warfare and unrest may not explain the cause of non-recovery of hoards. He believes the increase in the number of hoards in the AD 160s was a result of extravagant donativa and congiaria, and not the consequences of the Marcomanic wars: to support of his theory, he brings the argument that hoards ending with coins of Marcus Aurelius were found in areas where no Marcomanic invasions took place. ${ }^{24}$ Richard Reece, in his discussion on the interpretation of Roman coins stated that: $\leadsto A$ coin hoard as such cannot inform us whether it was never recovered for dramatic reasons linked to great historical events, or silly events linked to no more than domestic dramas. ${ }^{25}$ An analysis of the structure of coin hoards often shows that the reason for hoarding money was the economic conditions in the Empire. Roman financial history testifies that a deterioration in money (lower quality of metal, reduction of the weight of coins) encouraged the population to bury (or hoard) better quality money as quickly as possible, since it always had a nominal purchase value that was lower than the actual value of the metal from which the coin was minted. Numerous coin hoards show that the hoarding took place over an extended period, and this kind of hoard does therefore not reflect the structure of money in circulation at the moment at which the owner ceased hoarding money and buried it. ${ }^{26}$

\footnotetext{
23 CRAWFORD 1969, 76-81.

24 DUNCAN-JONES 1994, 77. In: GAZDAC 2012, 167.

25 REECE 1988, 265.

26 KOS 1997b, 376. Traditionally these hoards have
} been interpreted as having been buried with the intention of recovery but discoveries such as the Frome hoard have suggested the possibility that these hoards may have been ritual (or 'votive') deposits. Ritual deposition is a common explanation for prehistoric metalwork, and many, if not all, Iron Age coin hoards. 


\section{INTERPRETING INCOMPLETE HOARDS: THE CASES OF THE EMONA AND ČENTUR HOARDS}

When researching the Roman past of present-day Slovenia, written sources reveal very little information, sometimes even incorrect data due to the lack of knowledge of the area. In order to fill historical gaps, archaeological material and especially coins are therefore of significant importance. The biggest contribution to this field has been made with the publication since 1988 of the series Die Fundmünzen der römischen Zeit in Slowenien (FMRSI), which provides a complete picture of the Slovenian numismatic material, constantly updated with new finds. ${ }^{27}$

Among some circa 150 documented Roman hoards (the Celtic hoards being excluded), almost half of them date from the Late Antiquity. ${ }^{28}$ And among those, the two most famous - but also most problematic ones are the Emona and Čentur hoards, which date from the fourth century $\mathrm{AD}$, at the time of the usurpers Magnentius and Maxentius. Both hoards are exceptional, in terms of size and content, so that they can help us understand the course of important historical events of the time. However, both hoards had been discovered in exceedingly unfavorable circumstances, making the reliability of their interpretation problematic.

The Emona hoard of Roman medallions, heavy gold coins with a value of two or three solidi, was unearthed in Ljubljana in 1956, when foundations for a residential building were being dug where Emona's political, commercial, social, and religious centre used to be. One of the construction workers found a large gold coin, and the news spread quickly throughout the construction site, which set off a furtive and successful search. The National Museum initially acquired three gold coins from the workers for a small sum. Three more were acquired, through the National Bank

\footnotetext{
See BLAND 2013-2017.

27 KOS 1988; KOS-ŠEMROV 1995; ŠEMROV 1998; ŠEMROV 2004; ŠEMROV 2010.

${ }^{28}$ MIŠKEC 2012, 379.
}

where the workers tried to sell the coins. And Aleksander Jeločnik, curator of numismatics, managed to acquire a seventh one. Through further investigations, including contacts with colleagues and private collectors abroad, Jeločnik managed to reconstruct the size of the hoard and its partial composition, but the hoard remains incomplete: in addition to those seven salvaged specimens, which are preserved in the Numismatic Cabinet of Slovenia, some two-thirds of the hoard (which contained an estimated 22 gold coins) is dispersed. ${ }^{29}$ Unfortunately, the exact data of the find, which would have allowed the full reconstruction of the deposit and consequently its interpretation, were lost forever. ${ }^{30}$

The Čentur hoard, which consists of late Roman nummi, was unearthed in various places in 1935 (Čentur D), 1938 (Čentur C), 1944 (Čentur A), 1962 (Čentur B) and 1975 (Čentur E). World War II, and the tensions between Yugoslavia and Italy in 1939-1945 obviously had an impact on the recording of information surrounding the discoveries. The first part of the hoard (Čentur D) were discovered in 1935, of which 2.195 coins are now stored in the Archaeological Museum of Istria, in Pola. ${ }^{31} \mathrm{~A}$ few years later, an amphora with three to four thousand comparable coins was discovered in the same area, and the National Museum acquired 2.276 of them, whilst the rest was claimed to have been seized by the Italian carabinieri (although it is more likely that it was in sold in Trieste). ${ }^{32}$ Later on, in 1944, an inhabitant from Mali Čentur encountered coins while ploughing his field: he reburied the find, in order to excavate it after the end of the war. The municipal authorities of the area were notified about a part of the find, yet - having received a small compensation - the finder sold a small part of the remaining coins in Trieste. ${ }^{33}$ He claimed
29 JELOČNIK 1967; JELOČNIK 1968, 202.
30 MIŠKEC 2011, 822.
31 BRUSIN 1937. In: CALLEGHER 2019, 221.
32 JELOČNIK 1973, 16.
33 A small part of this find was likely the 695 reduced nummi published by PICOZZI 1964. The coins were 
Table 1. Identified specimens of the Emona hoards

\begin{tabular}{lcccc}
\hline Authority & Denomination & Mint & Date & Number of coins \\
\hline CONSTANS & triple solidi & Trier & $342-343$ & 1 \\
\hline CONSTANS & triple solidi & Thessaloniki & $342-343$ & 1 \\
\hline MAGNENTIUS & double solidi & Aquileia & $350-352$ & 6 \\
\hline MAGNENTIUS & triple solidi & Aquileia & $350-352$ & 11 \\
\hline
\end{tabular}

that the majority of the find was melted down into a copper sulphate compound known as blue vitriol, used for spraying grapevines, but the Museum managed to acquire 5.032 coins. When, in 1962, foreign illegal diggers used detectors and discovered more coins at that same location (three groups of 2,000 pieces each), the incident was reported to the authorities in Koper but only a small part of the hoard (2,042 coins) was seized and handed over to the National Museum of Slovenia in Ljubljana, the rest being sold in Trieste and dispersed on the numismatic market. In the last unearthing in 1975 (Čentur E), one gold coin of emperor Licinius with a golden fibula were discovered. ${ }^{34}$ So, the Slovenian National Museum today holds only slightly more than a third of the circa 18,000 coins found in Čentur. ${ }^{35}$

\section{COIN ANALYSIS OF THOSE HOARDS}

Both cases are incomplete hoards, and their analysis must take this fact into account. However, scholars have discovered information on the missing specimens of the Emona hoard. Similar reconstructions of dispersed finds were also done by Bastien and Metzger (1977), for the Arras hoard, and by Estiot (2011) for the so-called Corsica hoard. At the time of the discovery, Jeločnik had only managed to identify 13 coins from the hoard, ${ }^{36}$ but his work was continued by Alenka Miškec, and now some 19 of 22 specimens have been identified. In her article Miškec (2011) states

minted in just four Italian mints by the emperors Maximianius, Maxentius and Constantine. The majority of the coins were minted in Aquileia (510 nummi).

34 MIŠKEC 2002, 84-85.

35 JELOČNIK 1983, 215.

36 JELOČNIK 1976; JELOČNIK 1968. that there are supposedly two gold coins in private collections in Ljubljana, but it is not possible obtain data about them since the owners refused contact with the museum staff. With only 3 specimens left unidentified, the Emona hoard has been almost entirely reconstructed. The contents can be described as two triple solidi gold coins of Constans dating from 342-343 from Thessaloniki (which stand out in terms of period and content), while the rest of the hoard consists of double and triple solidi coins of Magnentius, made up of three different issues from the years 350, 351 and 352. ${ }^{37}$ Hoards from the mid-fourth century typically contain coins of the ruling emperor or his co-emperors, but rarely coins of his predecessors. All the coins from the hoard are very well preserved, as is indicated by their very uniform weights, ranging from 4.385 to 4.565 g per solidus. ${ }^{38}$ The fact that the coins are very well preserved also suggests that the owner must have obtained them almost directly from the treasury of Aquileia, perhaps as a donative. ${ }^{39}$

The study of the coins from the Čentur hoard is more difficult because of the many missing examples, but they seem to all date from the years 306-312 AD, which coincides with the time of the Tetrarchy and the rule of the usurper Maxentius. ${ }^{40}$ With the exception of 3 pre-reform antoninianii, all the coins are nummi, a denomination which had been introduced at the time of Diocletian's

\footnotetext{
37 MIŠKEC 2011, 825. A survey of the weights, calculated per single solidus and by issue, shows that the weight was relatively even over the entire period. There is no linear increase or decrease in weight.

38 MIŠKEC 2011, 825.

${ }^{39}$ MIŠKEC 2011. 825.

40 JELOČNIK 1973, 17.
} 
monetary reform in 295. Almost all the mints represented in the hoard belong to Maxentius' territories: Aquileia, Ticinum, Rome, Carthage and Ostia account for $97.1 \%$ of the finds, whilst Lugdunum, Treveri and Londinium only account for $0.6 \%$, and Siscia and eastern Balkan mints for $2.3 \%$. Of all the mints, Aquileia accounts for the majority, with $64.4 \%$ of the total.

The interpretation given by Aleksander Jeločnik (1973) is that Čentur A, Čentur B and perhaps Čentur D are parts of one single hoard, while Čentur $C$ is part of a different hoard, due to differences in its content. ${ }^{41}$ Only one gold coin, of emperor Licinius with a golden fibula, was identified as part of Čentur $\mathrm{E}$, and it is therefore impossible to attribute the find to one of the hoards with certainty. ${ }^{42}$ In 2015, Bruno Callegher suggested the parts of the Čentur hoard should be interpreted a single hoard, due to the unusual course of events surrounding the discovery and position of its unearthing. ${ }^{43}$ Unfortunately, the lack of contemporary documentation renders any argument difficult to prove.

Table 2. The number of recovered coins from the Čentur hoard (after CALLEGHER 2015)

\begin{tabular}{lcc}
\hline Hoard & $\begin{array}{c}\text { Coins seized a } \\
\text { preserved in } \\
\text { museums }\end{array}$ & $\begin{array}{c}\text { Coins which could } \\
\text { be attributed to } \\
\text { the hoard }\end{array}$ \\
\hline Čentur A & 5.032 & \\
\hline Čentur B & 2.042 & $\begin{array}{c}695+\text { ca. } 500 \\
\text { (unpublished) }\end{array}$ \\
\hline Čentur C & 2.276 & \\
\hline Čentur D & 2.195 & 562 (unpublished) \\
\hline Total & 11.545 & $+1,757=13,302$ \\
\hline
\end{tabular}

THE REASONS BEHIND THEIR BURIAL

The crucial information for the interpretation of these two hoards may

\footnotetext{
41 JELOČNIK 1973.

42 MIŠKEC 2002, 84-85.

43 The content of the Čentur $C$ hoard is published in JELOČNIK-KOS 1983.
}

lie in their location. The Emona hoard was discovered in the very centre of the ancient town, in the north-western area of the forum, which could suggest that the owner was a high-ranking civil official. ${ }^{44}$ Looking into the historical background of the period 350-353, both the emperor Constantius and the usurper Magnentius placed much focus on the IllyrianItalian border area. After the occupation of northeast Italy, Magnentius conquered Emona in 350, which remained under his control until 352: Magnentius' occupation of Emona could be connected to a hoard of 50 gold coins and 9 silver bars dating to the years $346 / 357 .{ }^{45}$ With its border position, the city gained a great strategic and economic significance. Although most of Magnentius' army was based with the emperor in Aquileia, Emona surely had to let a significant amount of army troops be based inside its walls, and Magnentius certainly needed to have well-paid confidants there. ${ }^{46}$ After his defeat at the battle of Mursa Major, late September 351, Magnentius retreated back into northeastern Italy. The following year Constantius II penetrated towards the West, conquered Emona, the Alpine defense system Claustra Alpium Iuliarum, and finally occupied Aquileia itself in early September 352. So he must have occupied Emona only a few days prior to Aquileia, and on this assumption we can date the burial of the hoard of Magnentius' multiple solidi at the end of August 352.47 A hoard of about 100 nummi dating to 351-352, which might have belonged to a soldier of Magnentius was discovered north of the Emona wall, as well

44 Bastien and Metzger (1977) in their discussion and description of coins from the Arras Hoard, found near Arras in northern France, proved that large sums of gold multiples struck for special occasions and anniversaries were usually handed out by high officials or by the emperor himself.

45 BRATOŽ 2014, 199.

46 JELOČNIK 1969, 216.

47 Bastien $(1964,126)$, believed that the Emona hoard was buried in 351 in the time of Magnentius' invasion into Illyricum, but that assumption was based on the since overthrown - belief that Emona was part of the Illyricum province. 
as two silver bars dating from the same time. ${ }^{48}$ Concerning the municipal area of Emona, sources make no mention of the city, and mention only the Atrans pass in connection with Constantius' first unsuccessful offensive in $351 \mathrm{AD}$, and Constantius' victory over Ad Pirum in $352 \mathrm{AD}$, followed by the occupation of Aquileia. ${ }^{49}$ Since the battle might have been a minor one, it is likely the sources left it out. ${ }^{50}$ Therefore our only source from this turbulent time in the city are hoards, which illustrate the critical situation of the time in which they were buried.

By seeking the reasons for the burial of the Čentur hoard researchers mostly relied on the configuration of the terrain in which the hoard was discovered, which would be a strategically good position and easily defendable. ${ }^{51}$ The massive hoard, interpreted as being part of a military pay-chest, could testify in favour of a military base on the route from Aquileia to Histria. The coins lead us largely into the year $310,,^{52}$ the period of Maxentius' usurpation: his authority, after Severus' defeat, extended in the northeast as far as the borders of Italy, which then included whole of Istria. Galerius had to withdraw across his border in the summer of 307 after his abortive march on Rome. At Carnuntum in November 308, Galerius arranged for Licinius to be promoted Augustus of the West, with the primary task of destroying the usurper in Rome. If the hoard is linked with military actions of that time, we would have proof that Licinius attacked on Italy in $310 \mathrm{AD}$, an offensive which is not documented by other historical sources. Two inscriptions from

\footnotetext{
48 BRATOŽ 2014 118-127.

49 JELOČNIK 1968, 216-217.

50 BRATOŽ 2014, 124.

51 See JELOČNIK 1973.

52 The sources from the Roman mint let us presume that the last issue from the hoard (represented by 452 nummi), was minted all through the year 309 and at least into the first part of the year 310. Significantly more precise in the dating of the emissions from the mint in Siscia, which was at the time of the burial of the hoard under Licinius' territory and which bring the last emissions of nummi of Maximinus Daia and Constantine the Great.
}

Pola and Parentium, on which the name of Licinius has been erased, as well as the closure of the Aquileia mint in the summer of 310, could confirm this hypothesis. ${ }^{53}$ However it remains unclear from where Licinius' forces would have arrived, as well as how and when Maxentius' would have regained the area. ${ }^{54}$ The only hypothetical confirmation of Maxentius' regaining control of Istria is Zosimus' mention of Maxentius' plan to gain control over Retia and the area of "Dalmatia and Illyricum" being only be possible by invading Istria first. But we do not know whether Maxentius ever realized this plan. ${ }^{55}$ Due to the lack of other archaeological evidence or contemporary documentation, and because of inconsistencies about the circumstances of the hoard discovery (mostly documented orally), there are still disagreements about the reason for its burial, as well as about its original content. ${ }^{56}$

\section{CONCLUSION AND FURTHER POSSIBILITIES OF HOARD STUDIES}

In addition to their numismatic value, coin hoards can be a valuable historical source, yet many historians ignore them and do not take them into account for their research. The reason for this may lie in the various problems connected to hoard analysis. When researching hoards as historical sources, we must be extremely careful in taking into consideration the circumstances of the

53 JELOČNIK 1973, 180.

54 PICOZZI 1976, 274 believes that Licinius had gained control of the area until the Soča river; BARNES 2011, 71 states Maxentius had regained control of the area, which was later controlled by Licinius in 312; while KUHOFF 2001, 859 and WITSCHEL 2002, 349 believe it is unlikely that Maxentius had regained control of the Istria region and that it is more likely the area stayed under Licinius' control until the battle at Cibalae.

55 ZOSIMUS 2, 14, 1. In: PASCHOUD 2003, 215-216.

56 CALLEGHER 2015 proposes a different interpretation of the hoard's burial, and considers the hoard to be a tax levy (made probably in the coastal towns of Trieste, Pola, Parenzo or in villages of Istria), rather than the witness of an act of war of which there is no other trace., but two inscriptions could ben of 3 pre-reform antoninians are nummi introduced by Diocletian's monetary reform. Ostia. matio 
discovery, the completeness of the hoard, the identification of the most recent coin, and the possible reasons for its burial. Even though incomplete hoards can be misleading in their interpretation, there are cases where other aspects, such as other archaeological evidence, the position of the hoard's unearthing or exceptional representation of specimens in the hoard, allow us to gain chronological and historical information.

As the Emona and Čentur hoards document, hoards are significant for historical research, indicating important historical events which are absent of written sources. But since they were both discovered in unfavourable circumstances and are incomplete, the level of reliability of their interpretation is questionable. In the case of the Emona hoard, quick action and yearslong tracking of the specimens has enabled it to be almost fully reconstructed. Its content, uniform and corresponding to historical circumstances, might testify in favour of their chronological and historical interpretation. Instead, despite multiple attempts to provide reliable interpretations of the Čentur hoard, the large missing portion of the hoard makes it impossible to confirm any hypothesis with certainty. Further research, and hopefully new information about the unearthing and content of the hoard, might enable us to gain new insights in the future. In order to reestablish the missing portion of the hoard, a project of an open-access database to collect all reliable and verified information was presented at the conference "Troppo grandi da studiare? - Too big to study?" in March 2018 in Trieste. ${ }^{57}$

Another important attempt to incorporate coin hoards into historical research, which offers an opportunity for a separate discussion in the future, should also be mentioned: Carlos Noreña and Georges Depeyrot have made valuable contributions to the study of history with numismatics by using hoard evidence to examine the frequency of coin types and thus the value of certain images in the overall visual

\footnotetext{
57 CALLEGHER, FAVRETTO 2019, 217-244.
}

program of a coinage ${ }^{58}$, as imperial coins have survived in sufficient numbers to allow quantitative analyses - a rare opportunity for ancient historians. ${ }^{59}$ To measure the relative frequency of coin types, Noreña proposes the tabulation of as many specimens as possible (from published hoards), combined with evidence from a group of hoards which provide a sample of the coinage produced by the imperial mint for the period between the earliest and latest coins in those hoards. Some hoards were surely the products of careful selection but this does not affect the value of a hoard-based sample for the study of the relative frequency of reverse types. ${ }^{60}$ Despite the fact that coinage is the medium to which the ancient historian has the most complete access, the potential quantitative treatment of hoards for iconographic and communicative research had so-far been virtually ignored. ${ }^{61}$ On the other hand, Nathan Elkins warns that studies of coin types should not be restricted to individual depictions or certain categories, without being aware of both the political and cultural history of the period, as well as of other coins that were struck and in circulation at the same time.

Historical and textual evidence, with a strong grasp of the numismatic contexts and methodologies (especially regarding emissions, die studies, and frequencies), are essential for anyone who approaches the question of numismatic iconography. ${ }^{62}$ In order to have a fuller understanding of how ancient coins can inform us about the ancient

\footnotetext{
58 NOREÑA 2001; DEPEYROT 2004; ELKINS 2009, 42.

59 Numismatists and economic historians have begun to exploit this mass of evidence, but the potential for quantitative treatment of imperial imagery and ideology has been virtually ignored. NOREÑA 2001, 147.

60 NOREÑA 2001, 146-168. The analytical value of such a sample for the study of imperial coin types rests on the crucial assumption that coins were not hoarded on the basis of their types.

61 NOREÑA 2001, 147.

62 Coins are products of the societies that produced and used them, and the images they bear were not produced in isolation of contemporary art historical trends. ELKINS 2009, 35.
} 
world, one must always examine the material in both art-historical and archaeological contexts as well. ${ }^{63}$ Therefore, by paying careful attention to multiple contexts and by trying not to succumb to their potential pitfalls, coin hoards can reveal an abundance of invaluable data for the better understanding of economic, political and military history as well as of the art and social history of the Roman Empire.

\section{REFERENCES}

\section{ASSENMAKER 2016}

Assenmaker, P., Zur Datierung der Stadtrömischen Münzprägung der Jahre 88-82, Neue Forschungen zur Münzprägung der römischen Republik (Nomismata 8), 99-123.

\section{BABELON 1961}

Babelon, J., Numismatique. In: Ch. Samaran (ed.), L'Histoire et ses méthodes, 29-392.

BARNES 2011

Barnes, T. D., Constantine. Dynasty, Religion and Power in the Later Roman Empire (Oxford: Wiley-Blackwell).

\section{BASTIEN 1964}

Bastien, P., Le monnayage de Magnence (350-353) (Wetteren: Éditions Numismatique romaine).

\section{BASTIEN/METZGER 1977}

Bastien, P. and C. Metzger, Le trésor de Beaurains (dit d'Arras) (Wetteren: Editions Numismatique Romaine).

\section{BRATOŽ 2014}

Bratož, R., Med Italijo in Ilirikom - Slovenski prostor in njegovo sosedstvo v pozni antiki (Ljubljana: Znanstvena založba Filozofske fakultete-Zveza zgodovinskih društev Slovenije-Slovenska akademija znanosti in umetnosti).

\section{BRUUN 1961}

Bruun, P. Numismatic notes and monographs no 146: Studies in Constantinian chronology (New York: Amereican NumisBLAND matic Society).

Bland, R., Crisisorcontinuity? Thedeposition of metalwork in the Roman world: what do

\footnotetext{
63 ELKINS 2009, 35.
}

coin hoards tell us about Roman Britain in the 3rd century AD? https://gtr.ukri. org/projects? ref=AH\%2FK000438\%2F1. Accessed 20 August 2019.

\section{CALLEGHER 2015}

Callegher, B., Un milione di denari sulla colina di Čentur. Testi e Studi di Storia Antica 27, 141-161.

CALLEGHER/FAVRETTO 2019, 217-244.

Callegher B., A. Favretto., Thousands of Tetrarchy folles all over the world: a hypothesis for re-composition. In: B. Callegher (ed.), Too Big to Study? - Troppo grandi da studiare? (Trieste), 217-244.

\section{ČENTUR}

Čentur-mestna občina Koper. Http://www. koper.si/index.php?page $=$ static\&item $=$ 2001506. Accessed 24 July 2019.

\section{DEPEYROT 2004}

Depeyrot, G., La propagande monétaire (64-235) et le trésor de Marcianopolis (251) (Wetteren: Moneta).

\section{DUNCAN 1993}

Duncan, G. L., Coin circulation in the Danubian and Balkan provinces of the Roman Empire: AD 294-578 (London: Royal Numismatic Society)

\section{DUNCAN-JONES 1994}

Duncan-Jones R., Money and Government in the Roman Empire (Cambridge-New York-Melbourne: Cambridge University Press).

ELKINS 2009, 25-46.

Elkins, N. T., Coins, contexts, and an iconographic approach for the 21st century. In: H.-M. von Kaenel and F. Kemmers (ed.), Coins in Context I: New Perspectives for the interpretation of coin finds (Frankfurt), 25-46.

\section{ESTIOT 2011}

Estiot, S., Le trésor d'or romain de Lava, Corse (terminus 272/273 de notre ère), Trésors Monétaires XXIV, 91-152.

\section{FITZWILLIAM MUSEUM}

Fitzwilliam Museum, Department of Coins and Medals: Coins as an historical source. Https://www.fitzmuseum.cam.ac.uk/dept/ coins/exhibitions/ancientcoins/index. html. Accessed 20 August 2019. 


\section{GAZDAC 2012}

Gazdac, C., 'War and Peace'! Patterns of Violence through Coin Hoards Distribution. Istros 18, 165-198.

JELOČNIK 1968

Jeločnik, A., Emonska najdba Magnencijevih multiplih zlatnikov, Arheološki vestnik 19, 201-220.

\section{JELOČNIK 1973}

Jeločnik, A., Čenturska zakladna najdba folisov Maksencija in tetrarhije (Ljubljana: Narodni muzej Slovenije).

JELOČNIK/KOS 1983

Jeločnik, A., P. Kos, Zakladna najdba Čentur - C. Folisi Maksencija in tetrarhij (Ljubljana: Narodni muzej Slovenije).

KELLER 1992

Keller, E., Raubgrabungen mit der Metallsonde-zur Situation in Bayern. Denkmalpflege Information 97, 2-5.

\section{KELLNER 1972}

Kellner, H.-J., Die Römer in Bayern (München: Süddeutscher Verlag).

\section{KEMMERS 2007}

Kemmers, F., Coins for a Legion: An Analysis of the Coin Finds from the Augustan Legionary fortress and Flavian canabae legionis at Nijmegen (Mainz am Rhein: Philipp von Zabern).

\section{KOS 1986}

Kos, P., The monetary circulation in the southeastern Alpine region ca. 300 B.C. - A.D. 1000. Denarni obtok na prostoru jugovzhodnih Alp 300 pr. n. š. - 1000 (Ljubljana: Narodni muzej Slovenije).

\section{KOS 1988}

Kos, P., Die Fundmünzen der römischen Zeit in Slowenien I-II (Berlin: G. Mann).

\section{KOS 1997A}

Kos, P., Interpretacija (antičnih) novčnih najdb. Metodologija - njene možnosti in pasti, Arheološki vestnik 48, 97-115.

KOS 1997B

Kos, P., Leksikon antične numizmatike (Ljubljana: Narodni muzej Slovenije).

\section{KOS 1982}

Kos, P., Numizmatika na Slovenskem. Zgodovinski oris, Arheološki vestnik 33, 235-257.

\section{KOS 2003, 52-57}

Kos, P., Managing the Numismatic Heritage in Slovenia. In: M. Campro (ed.), Actas de la VIII reunión del Comité Internacional de Museos Monetarios y Bancarios = Proceedings of the 8th Meeting of the International Committee of Money and Banking Museums (ICOMON) (Barcelona), 52-57.

\section{KOS/ŠEMROV 1995}

Kos, P. - Šemrov, Andrej, Die Fundmünzen der römischen Zeit in Slowenien III (Berlin: G. Mann).

\section{KUHOFF 2001}

Kuhoff, W., Diokletian und die Epoche der Tetrarchie. Das römische Reich zwischen Krisenbewältitung und Neuaufbau (284313 n. Chr.) (Frankfurt am Main: Verlag Peter Lang).

\section{MATIJAŠIĆ 1981-1982}

Matijašić, R., Il ripostiglio di monete romane di Centora (Čentur) custodito presso il Museo archeologico dell'Istria di Pola. Atti del Centro di ricerche storiche Rovigno 12, 33-56.

MIŠKEC 2002

Miškec, A., Die Fundmünzen der römischen Zeit in Kroatien: Abteilung XVIII Istrien (Mainz: P. von Zabern).

\section{MIŠKEC 2011}

MiškecA., The DoubleSolidus of Magnentius. In: N. Holmes (ed.), Proceedings of the XIVth International Numismatic Congress (Glasgow), 822-827.

NOLL 1954

Noll, R. Zur Vorgeschichte der Markomannenkriege, Archaeologia

Austriaca 14, 43-67.

NOREÑA 2001

Noreña, C., The Communication of the Emperor's Virtues, The Journal of Roman Studies 91, 146-168.

NMS

Numizmatični kabinet Narodnega muzeja Slovenije. Http://www.nms.si/index.php? Itemid $=46 \&$ catid $=27 \% 3$ Aoddelki\&id $=$ $537 \% 3$ Anumizmatini-kabinet $\&$ lang =sl\&option $=$ com_content $\&$ view $=$ article . Accessed 24 July 2019. 


\section{PASCHOUD 2003}

Paschoud, F., Zosime: Histoire nouvelle (Paris: Les Belles Lettres).

PETER 1996, 309-316

Peter, M., Bemerkungen zur

Kleingeldversorgung der westlichen

Provinzen im 2. Jahrhundert. In: C. E.

King/D. G. Wigg (eds.), Coin Finds and Coin

Use in the Roman World. The Thirteenth

Oxford Symposium on Coinage and

Monetary History (Berlin), 309-318.

PICOZZI 1964

Picozzi, V., Un ripostiglio di folles di

Massenzio, Numismatica 5, 181-198.

PICOZZI 1976

Picozzi, V., Una campagna di Licinio contro Massenzio non attestata nelle fonti letterarie, Quaderni Ticinesidi Numismatica e Antichità classiche 5, 267-275.

\section{REECE 1988}

Reece, R. Interpreting Roman hoards. World Archaeology 20, 2, Hoards and Hoarding, 261-269.

\section{REECE}

Reece, R. What Roman coins say. Https:// www.academia.edu/19865403/What_ Roman_coins_say. Accessed 16 August 2019.

\section{ŠEMROV 1998}

Šemrov, A., Die Fundmünzen der römischen Zeit in Slowenien IV (Berlin: G. Mann).

\section{ŠEMROV 2004}

Šemrov, A., Die Fundmünzen der römischen Zeit in Slowenien V (Mainz am Rhein: P. von Zabern).

\section{ŠEMROV 2010}

Šemrov, A., Die Fundmünzen der römischen Zeit in Slowenien VI (Wetteren: Moneta; Ljubljana: Narodni muzej Slovenije).

WARTENBERG KAGAN 2015

Wartenberg Kagan, U., Collecting Coins and the Conflict in Syria, ANS Magazine 4, 8-15.

\section{WITSCHL 2002}

Witschl, C., Meilensteine als historische Quelle? Das Beispiel Aquileia, Chiron 32, 325-393. 